from a partial attempt to map a whole retina on one cortex. There are also individual cells in the lateral geniculate nucleus that project on the cortex with no obvious pattern. If the eyes are removed at a sufficiently early stage of development, before they innervate the lateral geniculate nucleus, the map of the geniculate on the visual cotex is normal'. Thus, any disorder in the geniculo-cortical projection is secondary to the retinal defect and is not a direct result of the mutation.

Such studies suggest that the ferret system is ideal for unravelling the developmental patterns underlying the two proposed strategies for projecting the visual field on the brain, and should provide new insights into the mechanisms of interdependence in developing neural path- ways, as well as the establishment of topographical representations in different regions of the brain. The recent work shows promise for defining the mechanisms involved and may help to elucidate the genetic control of a component of neural development in vertebrates.

\footnotetext{
1. Lund, R.D. Science 149, 1506 (1965).

2. Guillery, R.W. Scient. Am. 230, 44 (1974).

3. Lund, R.D. Development and Plasticity of the Brain. (Oxford Univeesity Press, New York, 1978).

Kliot, M. \& Shatz, C.J.J. Neurosci. 5, 2641 (1981).

5. Dräger, U.C. Proc. natn. Acad. Sci. U.S.A. 82, 6716 (1985)

6. Guillery, R.W., Ombrellaro, M. \& LaMantia, A.L. Dev Brain Res. 20, 221 (1985)

Silver, J. \& Sapiro, J. J. comp, Neurol, 202, 521 (1981).

8. Huang, K. \& Guillery, R.W. Devl Brain Res. 20, 213 (1985)
}

R.D. Lund is Professor of Neurobiology, Ana tomy and Cell Science in the University of Pittsburgh School of Medicine, Pittsburgh, Pennsylvania 15261, USA.

\title{
Palaeoecology
}

\section{Unravelling human effects}

\section{from Peter D. Moore}

WHEN the early pollen analysts began to describe the pattern of Britain's vegetation following the last retreat of the glaciers, change in climate was seen as a major factor. The gradually rising temperature peaked some 7,000-5,000 years ago and has subsequently undergone a somewhat erratic decline. This was the basis of their climatic model and major vegetation changes, as reflected in fossil pollen spectra, were considered within this framework. The alder (Alnus glutinosa), a species showing postglacial expansion, has been regarded as a marker of changing climate, but new evidence' ${ }^{\prime}$ strengthens the claim that mesolithic man may have been involved in its spread ${ }^{2}$.

Only one species of alder, A. glutinosa, has been recorded in the British postglacial period and the expansion of its pollen, coincident with the decline of pine, was used by Godwin ${ }^{3}$ to mark the commencement of the Atlantic period (zone VIIa) of the Holocene in which the climate reached its optimum. Scattered $A$. glutinosa pollen was found in earlier postglacial deposits but was considered by Godwin' to represent local populations of the tree surviving in sub-optimal conditions. The expansion of this species was regarded as a consequence of increased Atlantic wetness rather than to increasing temperature. Thus the increasing presence of alder became an established datum which was assumed to be reasonably synchronous through England and Wales: it became synonymous with the Boreal-Atlantic transition.

Its value as a means of dating sediments was called into question by Oldfield and Statham ${ }^{5}$ in the Lake District (north-west England), and soon afterwards Smith pointed out that the changes necessary for alder to become more abundant within a forest and pine less so must ecologically be very complex. The climatic threshold of wetness, which was thought to induce this change, would have varied with geographical setting, and the forest itself would possess a degree of inertia resisting such a change, but the essentially climatic basis of the event was not questioned.

The expansion of alder with time was finally revealed by Smith and Pilcher's? collation of radiocarbon dates from various parts of the British Isles. The rise in alder varied between 7,500 and 5,000 years ago in different parts of Britian, but there was no strong geographical trend, except perhaps a tendency for earlier increases at lowland sites. The actual pattern of its expansion across Europe has been mapped by Huntley and Birks, whose pollen maps show that the tree was undoubtedly present in the west of France some 10,000 years ago, but its abundance there seemed to decline over the following 2,000 years. Where the British population arrived from and where it first entered the islands is unclear, but the pollen maps do suggest that the tree came westwards across northern Europe and entered Britain from the south-east, possibly along the Thames estuary through the early Holocene swampland.

But this proposed pattern is now considerably upset by the discoveries of Chambers and Price' in the peats of a valley mire in north-west Wales. They identify a very early alder expansion about 8,500 years ago. This follows suggestions already made by Chambers ${ }^{9}$ that the alder spread into Wales from the north-west, arriving later in the south. But even this pattern is an oversimplification, because at least one site in South Wales has re- vealed pollen dated to 7,900 years ago at Llangorse Lake ${ }^{10}$. These findings support an alternative idea that there was a source of alder to the west of Britain in the late or early postglacial, perhaps in lands now covered by the Irish Sea. But what was the actual cause of the population expansion of alder at these sites?

Smith ${ }^{2}$ suggests the sudden success of the species results from the disturbance of forest inertia by mesolithic man. This possibility was actually suggested first by McVean $^{11}$ in 1956; his ecological studies on alder showed it to be tolerant of competition and an efficient colonist, but he had no data supporting his idea of a human link. Nearly 20 years later, Smith reports evidence in South Wales of forest destruction associated with a rise in alder pollen, particularly the presence of charcoal in those horizons where the pollen becomes more abundant. There are similar records of charcoal at the site of Chambers and Price!.

Mesolithic peoples possessed a great potential for modifying their environment by the use of fire, to an extent that has only recently been realized ${ }^{12}$. There are several ways in which alder could benefit from such activities. Disturbance and burning of catchments leads to increased runoff of water, causing greater erosion and nutrient flushing in the basins, all of which would favour alder. The burning of reed swamp itself leads to the growth of shorter (but denser) and less robust reed shoots ${ }^{13}$, which could supply alder with opportunities for invasion. Also, the felling of alder leads to vegetative sprouting and cloning ${ }^{14}$ which could result in its rapid spread in swamp forests.

The decline in elm some 5,000 years ago; the decrease in lime somewhat more recently; and the spread of heathland, moorland and blanket bog are all now regarded as intimately linked with, if not actually caused by, the activities of prehistoric human activity. It now appears that the postglacial expansion of alder may be a consequence of its ability to benefit from human activities.

\footnotetext{
1. Chambers. F.M. \& Price, S.-M. New Phytol. 101, 333 (1985).

. Smith, A.G. New Phytol. 98, 35 (1984)

. Godwin, H. New Phytol. 39, $370(1940)$

4. Godwin. H. Phil. Trans R. Soc. B271. 47 (1975)

Oldfield. F. \& Statham. D.C. New Phytol. 62, 53 (1963)

Smith, A.G. Proc. R. Soc. B161, 331 (1965)

Smith, A.G. Proc. R. Soc. B161, 331 (1965).
7. Smith. A.G. \& Pilcher, J.R. New Phytol. 72, 903 (1973).

7. Smith, A.G. \& Pilcher, J.R. New Phytol. 72, 903 (1973).
8. Huntley, B. \& Birks. H.J.B. An Atlas of Past and Presen Pollen Maps for Europe: 0 - 13,000 Years Ago (Cambridge University Press, 1983).

9. Chambers. F.M. J. Ecol. 70, 445 (1983)

10. Chambers, F.M. Ecologia Mediterranea 11, 73 (1985)

11. McVean, D.N.J. Ecol. 44, 331 (1956).

12. Simmons, I.G. Dimbleby, G.W. \& Grigson, C. The En vironment in British Prehistory (eds Simmons. I.G. \& vironment in British Prehistory (eds Simmo
Tooley, M.J.) 82 (Duckworth. London, 1981)

3. Thompson. D.J. \& Shay, J.M. Can.J. Bot. 63, 1864 (1985)

14. Wilson, B.F. Patterson, W.A. \& O'Keefe, J.F. Can. J.
} Bot. 63, 1870 (1985)

Peter D. Moore is in the Department of Biology, King's College London, 68 Half Moon Lane, London SE24 9JF, UK. 